\title{
Achievements and Prospects of Coffee Research in Ethiopia: A Review
}

\author{
Demelash Teferi* \\ Ethiopian Institute of Agricultural Research, Jimma Agricultural Research Center. P.O. Box 192, \\ Jimma, Ethiopia.
}

*Corresponding Author: Demelash Teferi, Ethiopian Institute of Agricultural Research, Jimma Agricultural Research Center. P.O. Box 192, Jimma, Ethiopia.

\begin{abstract}
Ethiopia has unable to fully exploit from the unique natural and socio-cultural coffee opportunities, largely due to challenges related to coffee germplasm conservation, coffee research and extension services, coffee quality and marketing as well as linkages among the stakeholders. These constraints coupled with anthropological activities and climate changes are threatening arabica coffee genetic diversity and environmental sustainability. The national average coffee productivity remains too low and the quality standards are below expectations. This primarily stems from the predominantly coffee grown by small-scale farmers, most of whom are resource poor and depend on traditional practices. The Jimma Research Center (JRC) had made concerted works in collecting and preserving arabica coffee germplasm accessions (a total of 6923 original collections) at research field gene banks. The national coffee research has contributed in safeguarding the coffee sector from the possible irreversible losses due to the severe outbreak of coffee berry disease in the country. Coffee research has also played crucial contributions for increasing coffee productivity and production and export earnings. So far, 42 arabica coffee varieties (35 pure-lines and 7 hybrids) along with improved pre-and post-harvest handling practices have been generated for specific agro-ecologies of the country. The national coffee research projects were also designed for generation and promotion of improved technologies, information and knowledge at each agro-ecological zone. Nonetheless, the recommended and proven practices were less diffused due to several reasons including the weak linkages among stakeholders, low price share to growers, limited capacity building, shortage of credit access, shortage of tools and inputs and high costs, among others. Above all, there is an acute shortage of suitable varieties due to the absence formal coffee seed enterprises, except the JRC that supplies limited quantity of improved coffee seeds and seedlings. There should also be vibrant collaborations between coffee value-chain actors for encouraging sustainable production and price incentive mechanisms for the high quality coffee varieties and natural forest coffee landscapes, while promoting the green economy development strategy. In general, capacitated national coffee research is crucial for transforming the Ethiopian coffee industry. This would promote, inter alias, commercial-oriented coffee production and marketing for ensuring competitiveness of the value-chain actors and become center of excellence for research and training on arabica coffee. To modernize research programs, generate technologies, and adequately provide important services to actors along the value chain coffee Research strategy published in 2017, moreover on improving the entire value chain, highlighting strategic issues and recommendations across four pillars: 1) Research, 2) Extension and Production, 3) Value-addition and Marketing, and 4) Cross-Cutting and Sustainability (environmental and social) Comprehensive Ethiopian Coffee Strategy was developed in 2018, by Ethiopian coffee and Tea Authority in collaboration with EIAR and Technoserve. This paper highlights the status of major achievements and future prospects of coffee research in Ethiopia.
\end{abstract}

Keywords: variety development, coffee management and technology promotion.

\section{INTRODUCTION AND BACKGROUND}

Unlike coffee producing countries in Latin America and Asia, the coffee sector is constrained by the prevailing ineffective and inefficient policy frameworks in promoting coffee production, processing and marketing systems in several African coutries (ICO, 2015). Ethiopia has not fully exploited its vast natural endowment of genetic and unique natural coffee environments due to several factors, including insufficient access to finance and poor input distribution mechanisms for small-scale coffee farmers, predominant use of local landrace coffee types, traditional management, harvesting and postprocessing practices as well as lack of quality differentiated marketing system. The current climate 
change and variability has also noted to hamper the overall national coffee production and productivity.

Coffee plays a very important role in the national economy as a total of 5.3 million small-holders directly involved in producing coffee about 30 million people directly or indirectly depends in postharvesting activities. Ethiopia is a leading arabica coffee producer in Africa and ranks as the fifth producer and tenth coffee exporter in the world. Ethiopia needs to increase production and export volumes and optimize export prices. While Brazil exported 33 million bags in 2017, Ethiopia exported around $10 \%$ of that - just 3 million bags, behind Peru, Uganda, and India.

Coffee is still a leading export commodity and source of foreign exchange, though the shares of coffee export for the same period from agricultural commodities and total export revealed declining patterns, due to fluctuating world coffee prices and trade diversifications (agricultural, industrial and mining products). About half of the total volume of coffee produced is exported, while 40-45 percent is estimated to be consumed locally with per capita consumption of $1.33 \mathrm{~kg}$. The coffee ceremony occurs daily and thus plays a vital role in the cultural, spiritual and socio-economic life; particularly the current booming outdoor cultural coffee ceremony services can provide job opportunity to million people in the country,

The country has a diverse ecology and production system for growing coffee in all regional states with varying ranges of suitability and area coverage. Nevertheless, the major coffee growing areas are concentrated in the southwestern, southern, western, eastern and southeastern parts of the country. Limmu, Gimbi, Yirgacheffe and Harar are the most recognized brands that fetch premium prices in the international market (Figure 1). (Coffee is produced under different production systems, including forest (8-10\%), semi-forest (30-35\%), cottage or home garden (50-55\%), large-scale plantation (7$8 \%$ ) and semi-plantations. Accordingly, more than $90 \%$ of the total volume of coffee production comes from smallholders, whose average holding size is less than one hectare with low average productivity ranging from $200-250 \mathrm{~kg} / \mathrm{ha}$ (Workafes and Kassu 2000). Thus, Ethiopian coffee can be considered de facto organic and demanded for its finest cup flavor, thought small-scale coffee growers have not fairly benefited and remain vulnerable (Taye and Tesfaye 2002). It is still predominantly produced by small-scale farmers, many of whom are resource poor and do not use improved technologies and inputs, including agrochemicals. To ensure sustainability of coffee forest ecosystems and food security, it is critical to take urgent actions for mainstreaming shade-grown coffee landscapes through implementing sound quality accreditation and certification schemes. The use of geographical indicators and empowering small-scale farmers should get attentions for ensuring high quality traceability and consistency. Likewise, developing new branding and promoting quality forest products and services are very important for sustainable management and conservation of forest ecosystems.

In this regard, the important role of research-extension-marketing linkage in enhancing and productivity and quality cannot be overemphasized. To this end, Negusie et al. (2008) have indicated the attempts made by the JRC to foster links with coffee stakeholders to facilitate dissemination of improved coffee varieties, pre and post harvesting husbandry practices. Admassu et al. (2008) have also listed the major reinforcing factors with regard to adoption of coffee berry disease (CBD) resistant selections in the country.

Achieving the GTP targets in the coffee sector requires, inter alia, massive diffusion of improved and best technology options in small-scale coffee farming and private-public sectors. This may effected by supporting farmers' organizations, cooperatives, and unions to sustain their innovative power in coffee production and marketing through promoting information management and capacity development along the coffee value chains. Coffee research should focus in generation and prescaling-up of coffee technologies, including supply of reliable and high quality coffee seeds and seedlings for each area. The research-extension linkages should be considerably strengthened for establishment of multi-location demonstration sites preferably at farmers' training centers and speeding-up of the recommended coffee technologies (Girma et al. 2008) and best practices at the major and new potential coffee growth corridors of the country.

In Ethiopia, four national coffee conferences had been conducted, including the first coffee symposium in 1986, the second workshop on coffee and associated crops in 1995, the third on control of coffee berry disease in Ethiopia in 1999 and the fourth on four-decades of coffee reesearch and 
developmnt in 2007. However, only the later two national coffee events had published proceedings with their comprehensive information sources on Ethiopian coffee industry. The major achievements, constraints and challenges in the areas of coffee genetic resources, coffee research, coffee development, coffee quality, as well as marketing and policy-issues and linkages among stakeholders have been synthesized and documented in a Coffee Diversity \& Knowledge (Girma et al. 2008). It has underlined the need to develop and implement legal policy-frameworks on the utilization and protection of coffee genetic resources in Ethiopia, its birthplace. This paper was, therefore, prepared with the objectives to review five-decades of coffee research in Ethiopia and shade a light on the major achievements, challenges and future directions of coffee research in the country.

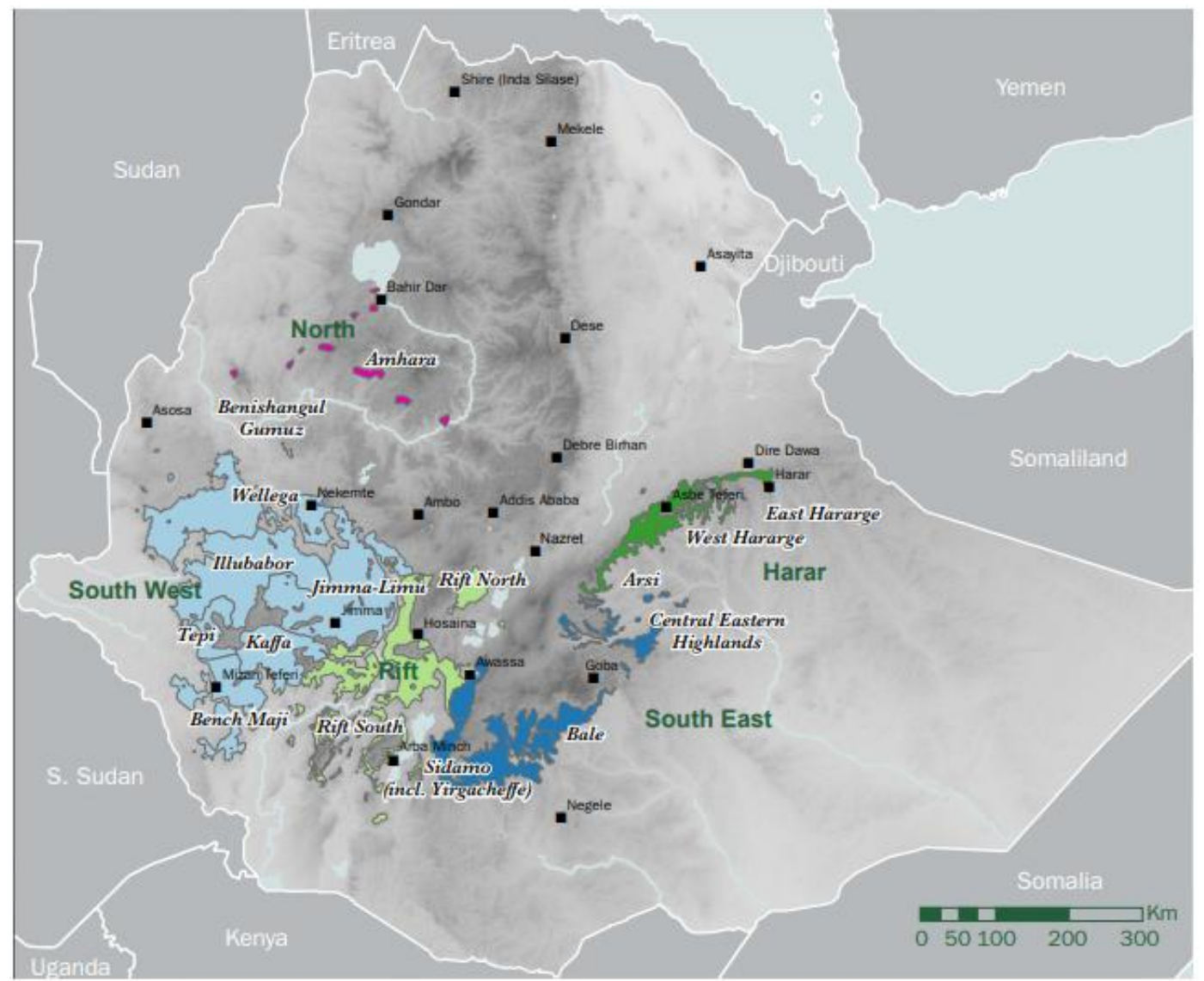

Source: "Coffee Farming and Climate Change in Ethiopia," Summary Report 2017, Kew Royal Botanic Gardens

Figure1. Coffee is grown throughout many of Ethiopia's regions

\section{HistoRY OF COFFEE RESEARCH IN ETHIOPIA}

\subsection{Establishment}

Coffee research in Ethiopia has been started before the establishment of the Melko-Jimma Research Center in 1966. In those early years, efforts were made to introduce coffee varieties from other countries, and these were tested for their adaptation at the Jimma Agricultural and Mechanical Arts School and later at the Jimma National Coffee Research Center. Coffee accessions were collected from India, Latin America, Africa, etc., and introduced to Ethiopia for their different characteristics. However, they performed poorly compared to the local collections. Very few had some good traits and most have failed to perform under different Ethiopian coffee agro-ecology.

The establishment and development of coffee research in Ethiopia has been reviewed by Paulos (2008). He pointed out that much more attention and strong support should be given to coffee research and that it should be made demand-driven and market-oriented. The systematic location of each of the established coffee research centers, sub-centers and testing sites was mainly targeted to represent the major coffee growing areas (Table 1). These were also augmented by various on-farm coffee adaptive research and demonstration sites stablished around each coffee research center in the country. Establishment of coffee technology training centers like Gomma-II is a good strategy to enable rapid 
scaling-up of improved coffee technologies, information and knowledge generated by the research system to the different stakeholders involved in the coffee production, processing and marketing value-chain process.

Table1. Coffee research centers in the major coffee growing areas of Ethiopia

\begin{tabular}{|c|c|c|c|c|}
\hline Center & $\begin{array}{c}\text { Establishment year } \\
(\mathbf{G C})\end{array}$ & $\begin{array}{c}\text { Total land holding } \\
\text { (ha) }\end{array}$ & Elevation (m.a.s.l) & Mandate Areas \\
\hline Jimma & 1967 & 183 & 1753 & Jimma/Limu \\
\hline Gera & 1974 & 280 & 1900 & Jimma/Gera highland \\
\hline Agaro & 1973 & 15 & 1630 & Limu/Jimma \\
\hline Metu & 1974 & 32 & 1550 & Illu Ababora \\
\hline Haru & 1998 & 76 & 1750 & West Wellega \\
\hline Mugi & 1973 & 27 & 1553 & Kelem Wollega \\
\hline Tepi & 1976 & 100 & 1200 & Tepi/Bebeka \\
\hline Mechara & 2005 & 50 & 1800 & West Hararghe \\
\hline Awada & 1997 & 31 & 1740 & Sidama \\
\hline Wenago & 1974 & 10 & 1850 & Yirgacheffe \\
\hline
\end{tabular}

The Jimma national coffee research coordinating center has a vision to be a leading center of excellence for arabica coffee research and training in the world. Several research activities have been carried out at the Jimma Research Center (JRC) and other trial sites to generate and promote improved coffee technologies, information and knowledge in the country. The major research areas include coffee genetics and breeding, coffee agronomy and physiology, control of diseases, weeds and insect pests, soils and water management, coffee quality and socio-economic. Accordingly, a good number of coffee resereach recommendations, including high yielding, disease resistant and top quality coffee varieties, improved management and post-harvesting technologies have been generated and transfered to various end-users and beneficiaries in the country. However, the impact for increasing coffee productivity and enhancing qualiy standards remain low due to various reasons. Among others, limited research capacity, lack of efficient technology transfer system and weak linkages among stakeholders along coffee value-chain actors were and still cited as bottleneck gaps that need due attentions (Girma et al. 2008).

In addition to its major contributions to safeguard the country's coffee genetic resources from loss due to CBD in 1971, the coffee research program had significant roles to the increased total coffee production, productivity and quality standards. This has played remarkable role for increased volume of export coffees and thus maximum foreign earning benefits. In general, the present development of the national coffee industry and its improved contributions would have been impossible without the commitments of coffee researchers and their outstanding achievements. As a result, Dr. Mesfin Ameha, senior coffee breeder, had the first the International Gold Mercury and national awards in 1986 for his finding on hybrid vigor in arabica coffee and the national coffee team had won the second rank and award of the Federal Science and Technology for the year 2012 from the research and innovation group for their outstanding achievements on Ethiopian coffee varieties of specialty areas. Besides, the JRC has received several recognitions and appreciations almost on all the coffee events at regional and federal levels in the country.

\subsection{Major Research Achievements}

\subsubsection{Coffee Genetic Resources}

Despite the constant threats to the Ethiopian coffee genetic resources, there are still different arabica coffee cultivars and local landraces possessing variations for improvements of yield and quality performances, disease resistance, drought tolerance, and other desirable agronomic traits. The local landrace coffee types are known by different vernacular names and growth characteristics at their geographical areas of origin in the country. According to Yacob et al. (1996), the Ethiopian coffee materials can be broadly categorized into three canopy natures, including open, intermediate and compact types. They could also be of the bourbon or typica types, which are quite different in their shoot and root growth systems, as well as their characteristic adaptations to specific localities and/or respective response to the varied management inputs. The local coffee types vary in their frequency of occurrence along rainfall gradients and soil profile depths, indicating their long term adaptations to 
specific environments. In addition to the numerous farmers domesticated coffee types, according to the recent update, a total of 5853 are being conserved at different coffee research field gene banks (Table 2) for research purpose, though it requires high costs for establishment and long-term farm management operations.

Table2. Status of coffee germplasm collections at research field genebanks

\begin{tabular}{|c|c|c|c|c|}
\hline Program/Type & Year (GC) & Original collection & Present number & \% conserved \\
\hline National collection & $1966-1990$ & 1633 & 1431 & 88 \\
\hline Exotic collection & $1968-1984$ & 190 & 78 & 41 \\
\hline CBD selection & $1973-1987$ & 868 & 825 & 95 \\
\hline Local landrace & $1994-2015$ & 4232 & 3519 & 83 \\
\hline Total & & $\mathbf{6 9 2 3}$ & $\mathbf{5 8 5 3}$ & $\mathbf{8 5}$ \\
\hline
\end{tabular}

According to the ISSR marker studies (Kassahu 2006), there was a clear differentiation among wild population in molecular characteristics whereby individuals collected from the same plot clustered together with strong group in undisturbed plots as compared with those from semi-disturbed ones. This result was found to be very useful for fingerprinting the diverse coffee genetic resources in Ethiopia. Moreover, development of coffee trees under forest ecosystems is impaired due to several biotic and abiotic stresses, including diseases, insect pests, low sunlight interception and high humidity (Demelash T and Kifle B.2018). These problems are particularly witnessed in the forest, semi-forest and homestead and/or garden coffee systems, indicating the need for incentives like premium prices through sound certifications. Arabica coffee germplasm accessions are seriously affected by different types of diseases, including coffee berry disease (CBD), coffee wilt disease (CWD) and coffee leaf rust. The spread of CWD is becoming a serious bottleneck threatening arabica coffee production and genetic diversity in the country. Hence, massive adoption of control practices, capacitating coffee research and development of disease resistance coffee varieties are among top priority areas.

The regulations on coffee germplasm exchange and equitable benefit sharing and access and benefit sharing of coffee genetic resources and farmers' indigenous knowledge need to be revised and approved by the Government. There seems to be a reluctance and lack of concern from most public and private institutions in protecting and safeguarding Ethiopia's coffee genetic resources (Giram et al. 2008). Policy and regulations on farmers' and researchers' property rights should be urgently put in place and implemented. There is also a need to strengthen coordination among the stakeholders in the coffee sector and the public as a whole in awareness creation and shared vision regarding the serious consequences of informal and illegal transfer and use of arabica coffee genetic resources in jeopardizing the nation's benefits from its unique natural coffee gene pools.

\subsubsection{Coffee Variety Development}

\section{$>$ Coffee Berry Disease Resistant Variety Development (1967-1981)}

The Jimma Research station commenced variety development activity in 1966/67. The first few years were the formative period, constructing offices, laboratories, greenhouses, and over all station development and infrastructure construction. During this period, some observation trials, more of agronomic, crop protection, processing studies, and adaptation trials were conducted. Basic research, which could be considered during the first phase, was started in 1968 and that continued until 1973. This was the period when the occurrence of coffee berry disease (CBD) was observed in Ethiopia. The focus of the research at this time was based on variety improvement by collecting coffee seeds from different parts of the country and introducing back coffee lines that were collected from Ethiopia and being evaluated in many different parts of the world that are usually called French Mission Collection. At the same time agronomic practices such as forest coffee management, spacing trials, fertilizer management, stumping of old trees, and pruning were studied.

The outbreak and spread of CBD took place during this period. It was also during this period that extension and research of coffee planned to work together and minimize the damage of CBD on the economy. Hence, the CBD control program was drafted during this period and large number of CBD resistant selections and collections were made and evaluated. Since this was a period of crisis of the coffee industry. This was the period where all professionals, support staff and expatriates worked 
together day and night. The work was supported by FAO and the EEC and the National Coffee Board was together with the research team. It was during this period $18 \mathrm{CBD}$ resistant selections were released and most of these are still under production, where three of them were withdrawn after few years of release.

\section{Hybrid Variety Development}

Since the beginning of hybrid variety development program with hybrid vigor study in 1978, a number of experiments on hybrid variety development were conducted. Consequently, the national coffee research program at the JRC has released seven hybrids (Bayeta et al. 1998, Ayano A, K Nasiro, T Benti and N Meknnen, 2019). They are suitable to the low and mid altitude (1000-1750 ma.s.l) in the southwestern coffee growing areas of the country. The observed heterosis and hybrid vigor revealed in the relatively higher yield advantages of coffee hybrids over their pure-line parents $(18-20 \%)$ had necessitated the research work to give peculiar emphasis to the development of more coffee hybrids (Behailu et al. 2008a). The coffee hybrids were found to be moderately resistant to CBD in contrast to the complete yield loss of local coffee types.

Mean yield of the hybrids ranged from 24-26 q/ha on search station and about 13-20 q/ha in farmers field. The presence of high level of heterosis in crosses among elite indigenous coffee (Coffea arabica L.) cultivars was reported for the first time by an Ethiopian coffee scientist Mesfin Ameha. The senior scientist acquire gold mercury medal for his outstanding achievement. The Ethiopian government also acknowledges the findings and offer award to the coffee scientist.

\section{$>$ Local Landrace Development}

The conventional method of screening contain several drawbacks: (1) difficulty to develop a number of varieties that adapt to all environments, (2) low preference of the released varieties by the local farmers when released to all areas, (3) adulteration of the typical quality of specific and known areas by introducing improved varieties originated in other areas. Cognizant of the aforementioned drawbacks noted with the conventional approach and the environmental diversity of the major coffee growing areas, a new breeding strategy has been designed while preparing ten years development plan in 1991. This new selection and breeding strategy is known as 'local landrace development program'. In this program, varieties are developed for each major agro-ecology or coffee growing area independently based on local landrace collections of the respective areas. The basic assumptions are that (1) local landraces have better adaptation in their areas of origin than cultivars introduced from other geographical and ecological origins, (2) farmers show more preference for local cultivars than those improved varieties introduced from other areas, (3) it is possible to maintain the typical quality of each locality and (4) it is market oriented in a sense that consumers preference for a specific locality can be maintained and origin based diversity of pure line coffee varieties can be produced from pure line selection breeding program for the major coffee growing specialty areas as presented below. Based on yield, disease resistance and quality, 11 selections were released in 2010 for Sidama, Yirgachefe, Wollega and Harrarghe coffee producing areas (MoARD, 2010).

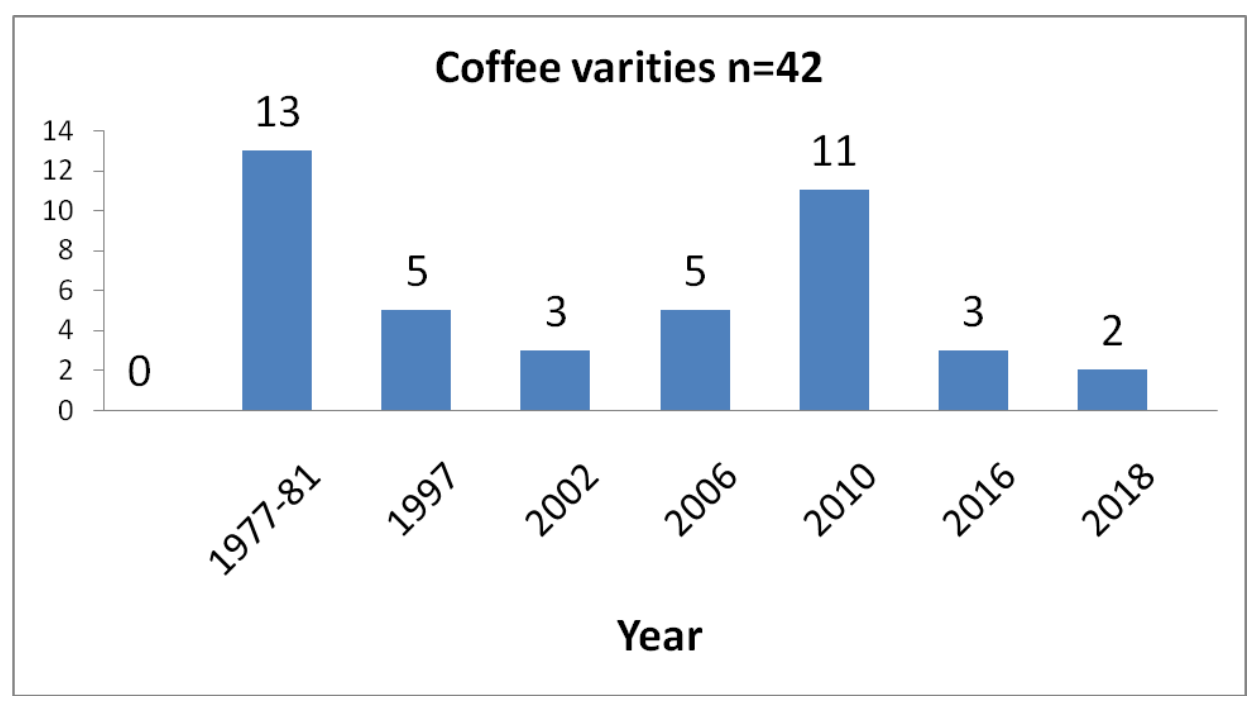

Figure2. Coffee varieties released from 1977-2018. 


\subsubsection{Coffee Management}

Coffee growing agro-ecologies in Ethiopia reveal highly variable climates, soil types, and elevations ranging from 550-2,400 m.a.s.l. The ideal coffee soil is characterized by a brown red color of clay origin, having an average depth of one meter or more. Well distributed rainfall with an annual average of $1400 \mathrm{~mm}$ or above, with aveage mimimum and maximum air temperatures of 10 and $24^{\circ} \mathrm{C}$, respectively is required for successful arabica coffee cultivation in Ethiopia (Paulos, 1994; Bayeta et al. 1998).

Coffee production and productivity can be improved by using improved agronomic and best management practices, such as adoption of best husbandry practices on old and new coffee plantations. Existing coffee stands suffer from poor returns, primarily due to old coffee trees, poor management and processing practices. Both the coffee plants and its native shade trees are often found being old and irregularly spaced, suggesting the need for expanding the use of appropriate stand adjustments and rejuvenation techniques (Anteneh et al. 2008). However, in doing so it is essential to take the utmost care in due time not to spread the infestation of coffee wilt disease, which had recently become the most devastating coffee disease in the major coffee production systems of the country.

Besides coffee varieties, the use of improved or best agronomic practices has been found to increase the rate of stand establishment, coffee yield and quality performances both under on-station and onfarm conditions. Above all, the land race coffee varieties and their multiplication and distribution initiative depicted an encouraging achievements in the major coffee growing areas of the country. The available coffee research findings were identified in the development strategy for their rapid scaling- up at specific agro-ecology and production system in the country. These include suitable coffee varieties or adaptable local coffee types, nursery management, plant density, pruning and training, rejuvenation methods, water harvesting and conservation, soil fertility management, application of plant nutrients and control of coffee pests, harvesting and processing methods, among others (Alemseged et al., 2015). The pre-scaling up of coffee nursery and field management practices carried out around coffee research centers in Jimma, Illubabor, West Wellega and Kelem Welega zones on a total of 120 farmers (JARC, 2015) showed promising results and evidenced the high demand by coffee farmers for improved technologies at all the intervention areas.

The use of best management practices is also equally important to maximize the genetic yield and quality potential of coffee varieties and landraces. In effect, there is adequate applied research findings in the areas of coffee seed preparation and nursery management and modern and forest coffee field management that have been recommended for the different coffee growing areas of the country (Yacob et al. 1996; Anteneh et al. 2008; Endale et al. 2008). Recommendations on the use of prominent coffee shade trees, population density, soil moisture conservation and small-scale irrigation schemes, soil fertlity and nutrient management, cropping patterns, control of coffee pests (weeds, insects and diseases) as well as use of best pre- and post-harvest management technologies (IAR 1996) should be demonstrated and scaled-out to incease coffee productivity and keep the inherent quality profiles (Desse 2008) of each area in the country.

The impacts of important pre- and post- harvest technologies to enhance coffee quality, the contribution of technical recommendation provided at every stage of production in the different agroecologies have been reviewed (Behailu et al. 2008b). However, information reaching farmers on effluent mangement in wet processing is inadequate. There is a great need in organizing small-scale farmers and promoting coffee cooperatives and unions, supporting large-scale private investors, intensifying training services, knowledge sharing and capacity building among coffee supply valuechains actors. These, among others, would help to sustain increased productivity, total production and high quality standards and enable the country to successfully compete in the global coffee markets and improve export earnings.

Moreover, new symptoms of drying have appeared on mature coffee trees, perhaps due to climate change and variability that has resulted in physiological disorders between vegetative and reproductive growth. This may be associated with continuous flowering and heavy crop loads due to changes in weather patterns with erratic rainfalls. The situation is aggravated by the outbreak of insect pests and diseases, requiring new solutions to revive arabica gene pools from possible fast and irreversible losses. Thus, multiple site conservation, utilization and management of arabica coffee populations by supporting the complementary use of in-situ and ex-situ approaches is important for national breeding program and development of the coffee sector. 


\subsubsection{Coffee Technology Promotion}

In coffee, various technology transfer mechanisms are employed to promote wide use of improved technologies across the country rapidly. These include demonstration sites, supplying improved seeds and seedlings, training and advisory services, field-days, farmers' research group, partners' council meetings, publications, on-air, etc. Among which, multiplication and distribution of improved planting materials is the major option. According to Taye et al. (2012), neither private nor public enterprises are engaged in producing and trading certified coffee seeds and seedlings. And there is an acute shortage of coffee seeds and seedlings, hampering scaling-up of successful technologies in the country. For this, suitable and adaptable coffee technologies should be widely demonstrated and transferred to the end users across the country. However, there is still lack of apropriate technologies had been the major bottleneck problem hidering rapid expansion of modern and/or semi-commercial coffee production system in the country. There should be active collaboration to create access to inputs and including seeds and seedlings. The results indicate that the demand for coffee seed significantly surpasses the supply from coffee research centers and the gap is increasing from year to year. Despite the increasing mismatch, an integrated informal and formal coffee system is lacking at regional and national levels, which calls for government support for authorizing and establishing coffee seed system in the country.

The Jimma Research Centre (JRC) is the only public institution that had taken the initiative of multiplying and supplying basic coffee seeds, from 1979-2016/17 a total amount of 258.2 ton seeds of the released CBD resistant and adaptable varieties were produced and distributed. Nonetheless, the limited endeavor of the JRC has played a considerable role for dissemination and adopation of improved coffee technologies by innovative famers, private and state owned farms throughout the country. Taye et al. (2012) reported the experiences coffee stakeholders in production and supply of improved basic coffee seeds and seedlings.

Moreover, a total of 22 seed orchards and 18 farmers' research-extension groups were established as future coffee seed sources awaiting for urgent action to be accredited as legal seed producers at each locality.

Despite their significant yield advantages, the hybrid coffee varieties remained shelved till the implementation of the research for development approach of the EIAR in 1998 (Behailu et al., 2008a). between 2015 - 2018 About 26,800 hybrid coffee seedlings were produced and distributed to the target areas of the Jimma and Kafa and Iluababora zones. Wondyifraw et al. (2008) reviewed the historical background of large-scale clonal propagation of coffee through tissue culture and the status of protocol optimization efforts for in vitro propagation of Ethiopian coffee hybrids. The preliminary results from the ex-vitro acclimatization and hardening-off activities were so encouraging to warrant subsequent commercialization of the technology.

\section{Constraints AND Challenges}

- Limited or lack of improved technologies with regard to coffee varieties (both pure lines and hybrids), agronomic practices, soil and water management, crop protection, coffee processing and quality improvement for the different coffee growing agro-ecological zones and for specific potential localities in the country;

- Lack of technology package recommendations for known coffee brands and specific niches;

- Inadequate capacity of technology multiplication for example, multiplication of seeds and seedlings of improved coffee varieties;

- Less research focus on the relationship between improved technologies and coffee quality;

- Limited research in integrated approaches to prevent and control coffee diseases and pests;

- Less attention given to participatory research approach and stakeholders involvement, while developing technologies;

- Less appreciation given to farmer's indigenous knowledge on disease and pest management, landrace development, soil and water management practices;

- Less attention given to detailed characterization and sustainable conservation and utilization of natural resources and diversification approach in the coffee based farming systems of the country;

- Inadequate research fund, laboratory and field facilities, trial sites and trained human power to strengthen national coffee research program; 
- Lack of coffee database and networking to assist the national coffee research system;

- Lack of comprehensive research on value addition and by-product utilizations.

4. FUTURE RECOMMENDATIONS

- Coffee research activities should be extended to uncovered areas in the different coffee growing agro-ecologies of the country;

- Coffee research should focus on package technology generation with farmers' participatory approach and evaluation before release for each specific locality/ niche and farming/production system;

- All research activities and technologies should give due emphasis to coffee quality as a major priority for each agro-ecology;

- Coffee research should focus on extensive collection, characterization and maintenance of coffee genetic resource and enhance genetic diversity in each coffee growing agro-ecology;

- Modern coffee improvement technologies such as biotechnology (tissue culture and molecular characterization and marker assisted selections) should be strengthened;

- Research should be strengthened in crop protection /coffee disease and pest management/ and Development of location specific CBD resistant cultivars and multiple diseases resistance including coffee wilt and leaf rust) as long-term solution. There is a need to strengthen laws and regulations for coffee wilt disease management (sanitation and quarantine), extensive training to the farmers in uncovered areas and strengthen the epidemiological studies;

- Detail characterization studies on nutrient status of coffee soils, soil and plant sample test-based fertilizer recommendation, integrated nutrient management along with identification of appropriate source of nutrients and compost accelerating methods for organic fertilizer options;

- Develop soil-coffee -climate interactions database, soil erosion control studies, coffee-water requirement, develop package technologies for irrigated coffee production (ecophysiological investigations) in view of climate change;

- Due attention should be given to farmers' indigenous knowledge of disease, pest, soil and water management and others, while designing/planning research activities for each coffee growing agro-ecology;

- Strengthen policy research for the use of waste management, post harvest and value addition research (both primary and finished products) need priority;

- Technology multiplication capacity (e.g. multiplication of seeds and seedlings of improved coffee varieties) should be improved via encouraging private investors with the view to meet the prevailing demand of all stakeholders;

- Coffee diversification research should focus on economically feasible and market oriented cropping systems, which also ensure food security, biodiversity conservation, agroforestry and ecosystem sustainability;

- Skilled human power, facilities and budget should be fulfilled for the National Coffee Research Program in order to be competitive in supplying quality coffee in sufficient quantity to the world market as demanded;

- National coffee funds (levies, taxes, sales, etc) should be established/secured from GOs, NGOs and relevant private stakeholders to promote the coffee sector and maintain natural resources, for biodiversity and friendly ecosystem services; and

- There is a need to strengthen the research system by establishing reliable coffee database and networking systems with the relevant local, regional, and international institutions. There is also a strong need for technology shopping to save resources, and gain research experiences from other coffee growing countries.

\section{REFERENCES}

[1] Admassu Shibru, Zekarias Shumeta and Tsegaye Gigey 2008. Adoption of improved coffee technologies in Ethiopia. pp: 357-370. In: Girma Adugna, Bayetta Belachew, Tesfaye Shimber, Endale Taye and Taye Kufa (eds.).Coffee Diversity and Knowledge. Proceedings of a National Workshop Four Decades of Coffee Research and Development in Ethiopia, 14-17 August 2007, Addis Ababa, Ethiopia. 
[2] Alemayehu Teshome, Esayas Kebede and Kassu Kebede 2008. Coffee development and marketing improvement plan in Ethiopia. pp: 375-381. In: Girma Adugna, Bayetta Belachew, Tesfaye Shimber, Endale Taye and Taye Kufa (eds.).Coffee Diversity and Knowledge. Proceedings of a National Workshop Four Decades of Coffee Research and Development in Ethiopia, 14-17 August 2007, Addis Ababa, Ethiopia.

[3] Alemseged Yilma, Tesfaye Shimber, Taye Kufa and Endale Taye 2015. Manual on modern coffee tree management (Amharic version). EIAR, Addis Abeba, Ethiopia.

[4] Anteneh Netsere, Endale Taye, Taye Kufa and Tesfaye Shimber 2008b. Research on Arabica forest coffee management. pp. 196-200. In: Girma Adugna, Bayeta Belachew, Tesfaye Shimber, Endale Taye and Taye Kufa (eds.). Coffee Diversity \& Knowledge. Four Decades of Coffee Research and Development in Ethiopia, 14-17 August 2007, Addis Ababa Ethiopia.

[5] Anteneh Netsere, Endale Taye, Tesfaye Shimber, Taye Kufa and Alemseged Yilma 2008a. Pre-planting management of Arabica coffee in Ethiopia. pp. 178-186. In: Girma Adugna, Bayeta Belachew, Tesfaye Shimber, Endale Taye and Taye Kufa (eds.). Coffee Diversity \& Knowledge. Four Decades of Coffee Research and Development in Ethiopia, 14-17 August 2007, Addis Ababa, Ethiopia.

[6] Ayano A, K Nasiro, T Benti and N Meknnen, 2019. Hybrid coffee variety verification trial for yield and yield components for mid- and low-lands of southwest coffee growing areas. Inter J Agri Biosci, 8(5): 237-241.

[7] Bayeta Ballechew, Behailu Atero and Gibramu Temesgen (1998). Description and production recommendations for new cultivars of Arabica coffee. IAR Research Report, No 34.

[8] Bayetta Bellachew, Behailu Atero, Fikadu Tefera, Ashenafi Ayano and Tadesse Benti $2008 . \quad$ Genetic Diversity and Heterosis in Arabica Coffee. pp:50-57. In: Girma Adugna, Bayeta Belachew, Tesfaye Shimber, Endale Taye and Taye Kufa (eds.). Coffee Diversity \& Knowledge. Four Decades of Coffee Research and Development in Ethiopia, 14-17 August 2007, Addis Ababa, Ethiopia.

[9] Behailu Atero, Bayetta Belachew, Fikadu Tefere, Melaku Addisu, Tadesse Benti and Ashenafi Ayano (2008a). Developing coffee hybrid varieties. pp: 99-105. In: Girma Adugna, Bayeta Belachew, Tesfaye Shimber, Endale Taye and Taye Kufa (eds.). Coffee Diversity \& Knowledge. Four Decades of Coffee Research and Development in Ethiopia, 14-17 August 2007, Addis Ababa, Ethiopia.

[10] Behailu Woldesenbet, Abrar Sualeh, Negussie Mokonen, and Solomon Endris 2008b. Coffee processing and quality research in Ethiopia. pp: 307-317. In: Girma Adugna, Bayeta Belachew, Tesfaye Shimber, Endale Taye and Taye Kufa (eds.). Coffee Diversity \& Knowledge. Four Decades of Coffee Research and Development in Ethiopia, 14-17 August 2007, Addis Ababa, Ethiopia.

[11] Bellachew Bellachew and Labouisse JP 2006. Arabica coffee (Coffea arabica L.) local landrace development strategy in its center of origin and diversity. pp: 818-826. In: Proceedings of the 21st International Conference on Coffee Science (ASIC), September 11-15, 2006, Montpellier, France.

[12] CSA, 2015. Federal Republic of Ethiopia, Central Statistical Agency, Agricultural Sample Survey Report on Area and Production of Major Crops, 2014/2015, Vol. 1, Statistical Bulletin 578, May 2015, Addis Ababa, 121P.

[13] Desse Nure 2008. Mapping Quality Profiles of Ethiopian Coffee by Origin. pp: 317-327. In: Girma Adugna, Bayeta Belachew, Tesfaye Shimber, Endale Taye and Taye Kufa (eds.). Coffee Diversity \& Knowledge. Four Decades of Coffee Research and Development in Ethiopia, 14-17 August 2007, Addis Ababa, EIAR, Ethiopia.

[14] Endale Taye, Taye Kufa, Anteneh Netsere, Tesfaye Shimber, Alemseged Yilma, Amanuel Asrat and Tesfaye Ayano 2008. Research on Arabica coffee field management. pp. 187-195. In: Girma Adugna, Bayeta Belachew, Tesfaye Shimber, Endale Taye and Taye Kufa (Eds.). Coffee Diversity \& Knowledge. Four Decades of Coffee Research and Development in Ethiopia, 14-17 August 2007, Addis Ababa, EIAR, Ethiopia.

[15] Fekadu Tefera, Melaku Adissu, Bayetta Belachew, Behailu Atero, Tadesse Benti, Ashenafi Ayano (2008). Developing improved pure line coffee varieties for different coffee growing areas of Ethiopia. pp: 64-70. In: Girma Adugna, Bayeta Belachew, Tesfaye Shimber, Endale Taye and Taye Kufa (Eds.). Coffee Diversity \& Knowledge. Four Decades of Coffee Research and Development in Ethiopia, 14-17 August 2007, Addis Ababa, EIAR, Ethiopia.

[16] Girma Adugna, Bayeta Bellachew, Tesfaye Shimber, Endale Taye and Taye Kufa 2008. pp: 505-510. In: Girma Adugna, Bayeta Belachew, Tesfaye Shimber, Endale Taye and Taye Kufa (Eds.). Coffee Diversity \& Knowledge. Four Decades of Coffee Research and Development in Ethiopia, 14-17 August 2007, Addis Ababa, Ethiopia.

[17] ICO, 2015. Coffee Production Data. www.ico.org. Accessed on August 8, 2015: International Coffee Organization. 
[18] IAR/JARC. 1996. Recommended Production Technologies for Coffee and Associated Crops. Institute of Agricultural Research Jima Research Center.

[19] JARC 2015. Jimma Agricultural Research Center Profile for the Period 2014/15. 24 P. In: Getachew WoldeMechael, Leta Tullu, Kifle Belachew, Workneh Bekere, Ashenafi Ayano (eds.), Jimma Agricultural Research Center (JARC), EIAR, Jimma.

[20] Kassahun Tesfaye 2006. Genetic diversity of wild coffee arabica populations in Ethiopia as a contribution to conservation and use planning. PhD dissertation. University of Bonn, Bonn, Germany.

[21] Ministry of Agriculture and Rural Development, MoARD 2010. Ministry of Agriculture and Rural Development, Animal and Plant Health Regulatory Directorate, Crop Variety Registration Issue No. 12 June, Addis Ababa, Ethiopia.

[22] Negusie Etefa, Derese Teshome, Berhanu Megerssa and Getachew WoldeMicheal 2008. pp: 345-356. Research Center-based extension interventions on improved coffee technologies. In: Girma Adugna, Bayeta Belachew, Tesfaye Shimber, Endale Taye and Taye Kufa (Eds.). Coffee Diversity \& Knowledge. Four Decades of Coffee Research and Development in Ethiopia, 14-17 August 2007, Addis Ababa (Ghion Hotel), EIAR, Ethiopia.

[23] Paulose Dubale (2008). Retrospect and prospect of coffee research in Ethiopia. pp: 6-10. In: Girma Adugna, Bayeta Belachew, Tesfaye Shimber, Endale Taye and Taye Kufa (Eds.). Coffee Diversity \& Knowledge. Four Decades of Coffee Research and Development in Ethiopia, 14-17 August 2007, Addis Ababa (Ghion Hotel), EIAR, Ethiopia.

[24] Paulsos Dubale 1994. Mineral fertilization of coffee in Ethiopia. Institute of Agricultural Research, Addis Ababa, Ethiopia.

[25] Taye Kufa and Tesfaye Shimber 2002. Organic coffee production: hope for small-scale farmers in Ethiopia. pp: 1246-1252. Proceedings of the $19^{\text {th }}$ International Conference on Coffee Science (ASIC), May $14^{\text {th }}-18^{\text {th }}, 2001$, Trieste, Italy,

[26] Taye Kufa, Ashenafi Ayano, Alemseged Yilma, Teshome Kumela, Wondiyfraw Tefera 2012. The contribution of coffee research for coffee seed development in Ethiopia. E3 Journal of Agricultural Research for Development, 1(1): 009-016.

[27] Teferi D and K Belachew, 2018. A review of coffee diseases research in Ethiopia. Inter J Agri Biosci, 7(2): $65-70$.

[28] JARC (2015). Jimma Agricultural Research Center Profile for the Period 2014/15, July 2015, EIAR, Jimma, Ethiopia.

[29] Taye Kufa, Anteneh Netsere, Tesfaye Shimber, Endale Taye and Alemseged Yilma 2008. Intercropping coffee with other crops. pp. 201-208. In: Girma Adugna, Bayeta Belachew, Tesfaye Shimber, Endale Taye and Taye Kufa (eds.). Coffee Diversity \& Knowledge. Four Decades of Coffee Research and Development in Ethiopia, 14-17 August 2007, Addis Ababa, Ethiopia.

[30] Wondyifraw Tefera, Ramos A., Filepe M., Alemayehu Teressa and Zerihun Abebe. 2008. Tissue culture multiplication techniques for coffee. pp: 106-119. In: Girma Adugna, Bayeta Belachew, Tesfaye Shimber, Endale Taye and Taye Kufa (eds.). Coffee Diversity \& Knowledge. Four Decades of Coffee Research and Development in Ethiopia, 14-17 August 2007, Addis Ababa, Ethiopia.

[31] Workafes WoldeTsadik and Kassu Kebede 2000. Coffee production systems in Ethiopia. pp: 99-106.

[32] in Ethiopia; a review. pp. 58-64. Proceedings of the workshop on control of coffee berry disease in Ethiopia, 13-15 August 1999, Addis Ababa, Ethiopia.

[33] Yacob Edjamo, Tesfaye Shimber, Taye Kufa, Alemseged Yilma, Takele Negewo, Anteneh Nestere and Bekele Bogale 1996. Advances in coffee agronomy research in Ethiopia. pp. 40-45 In: Tenywa J.S., Adipala Ekwamu, M.W. Ogengalatogo (eds). Proceedings of Inter-Africa Coffee Organization (IACO) Workshop, 4-6 Sept., 1995, Kampala, Uganda.

Citation: Demelash Teferi, "Achievements and Prospects of Coffee Research in Ethiopia: A Review" International Journal of Research Studies in Agricultural Sciences (IJRSAS), 2019; 5(11), pp. 41-51, http://dx.doi.org/10.20431/2454-6224.0511006

Copyright: (C) 2019 Authors. This is an open-access article distributed under the terms of the Creative Commons Attribution License, which permits unrestricted use, distribution, and reproduction in any medium, provided the original author and source are credited. 